\title{
'Islamofascism': Four Competing Discourses on the Islamism-Fascism Comparison
}

\author{
Tamir Bar-On
}

School of Social Sciences and Government, Tec de Monterrey,

Campus Querétaro, Querétaro, México

tbaron@itesm.mx

\begin{abstract}
With the dramatic rise of the Islamic State of Iraq and Syria, we witnessed the revival of the Islamism-fascism comparison. This paper begins with a short history of the Islamism-fascism comparison. It then argues that both Islamism and fascism are coherent political ideologies. The author proposes a four-fold typology of different discourses in respect of the Islamism-fascism comparison, which are called 'Thou shall not compare', 'Islamofascism, 'Islamofascism as epithet', and 'Dare to compare'. It's concluded that we should compare Islamism and fascism, but that the two ideologies are distinctive, totalitarian ideologies. Clerical fascism is the closest ideologically to Islamism, although it is also a distinctive political ideology.
\end{abstract}

\section{Keywords}

Islamism - fascism - Islamofascism - political ideologies - discourses - intellectuals totalitarianism - clerical fascism

In 2016, Hamed Abdel-Samad published a provocative book entitled Islamic Fascism in which he suggested that the 'Islamofascist' worldview has its origins with the Muslim Brotherhood, which 'had always eulogized the principles of Adolf Hitler and Benito Mussolini.'1 Abdel-Samad also suggested an association between the 'Islamofascist' ideas of the Grand Mufti of Jerusalem Amin

1 Premanand Mishra, 'Islamic Fascism Book Review,' Contemporary Review of the Middle East 4, no. 1 (2016): 122.

(C) BAR-ON, 2018 | DOI 10.1163/22116257-00702005

This is an open access article distributed under the terms of the prevailing CC-BY-NC license at the time of publication. 
al-Husseini: His hatred for Jews, support for Hitler, and praise for the Holocaust. ${ }^{2}$ In the midst of us airstrikes against the Islamic State of Iraq and Syria (ISIS), Salam Saadi, the editor-in-chief of Rudaw Kurdish, pinned the fascist label on the IsIs:

The Islamic State (Is) is nothing but a blend of Islamic fatalism and radical nationalism that tries to compensate for all the past humiliations of the Arab world. This makes Is a fascist 'state'.

The fascination of Islamic radicalism with fascism is not new. Hassan Banna, the Egyptian founder of the Muslim Brotherhood, said in a book in 1935 that Italian fascist and dictator Benito Mussolini was practicing one of the principles of Islam.

The relationship between Islamic extremism and fascism is historical. The extremists have used the Koran to look down on and degrade nonArabs, boasting that God sent his latest revelation in their language. ${ }^{3}$

The author adds that the list of enemies against the ummah [Muslim community of believers] is long, while Isis 'cannot tolerate differences' and hence destroys 'foreign' places of worship and systematically kills Christians, Yezidis, Shabaks, Shi'ites, and Kurds. While IsIs was never technically a state recognized by the international community, Saadi views IsIS as a variant of 'Islamic fascism' because of its penchant for pan-Arab ultra-nationalism mixed with the desire to institute the sharíah and Caliphate; the mimicry of fascism and Nazism by early Islamists such as Hassan al-Banna (1906-1949), the Egyptian founder of the Muslim Brotherhood; the racialism of the Arabs despite the universalist message of al-qur'ān [Koran]; the conspiratorial worldview; the desire to purge the Muslim Arab nation of 'impure elements' both at home and abroad; and the hatred of cultural, religious, and ideological differences. While this might be true, does this necessarily make Is Is 'fascist'?

One might question Saadi's view that ISIS is 'a blend of Islamic fatalism and radical nationalism.' After all, Isis follows a pan-Islamist rather than nationalistic or pan-Arab ideology. IsIs fights the Kurds not because they are Kurds, but rather because they are rather secularized and insufficiently Muslim. We should remember that the ranks of Isis includes not only Arabs, but also

2 Hamed Abdel-Samad, Islamic Fascism (New York: Prometheus Books, 2016), 18.

3 Salam Saadi, 'Islamic State or Islamic Fascism?' Rudaw Kurdish, August 21, 2014, accessed November 5, 2017, http://rudaw.net/NewsDetails.aspx?PageID=61425. 
Chechens, Uighurs, South Asians, and white and black Western converts to Islam. For ISIs, nation-states divide Muslims and the true vocation of Muslims is to create a transnational community of believers governed by shariah.

What is of interest here is Saadi's characterization of IsIS as 'fascist'. The term 'Islamofascism' has largely disappeared from the lips of us and Western policymakers and academics, no doubt inspired by fear of alienating the Muslim world. President Trump prefers the term 'radical Islamic terrorism,' although his former chief strategist Stephen Bannon called 'jihadist Islamic fascism' the latest phase of an existential struggle and 'war' between the JudeoChristian West and Islamic world. ${ }^{4}$ President Barack Obama's administration did not evoke comparisons between Islamists and fascists, as it sought to win hearts and minds for its less aggressive military posture in the Muslim world compared to the George W. Bush administration. Yet, from 2014 to 2017 journalists, bloggers, and some academics equated IsIS or other Islamist groups such as Hamas with fascism. ${ }^{5}$

The fascism-Islamism comparison reached its apogee in the post-9/11 climate. Stephen Schwartz claims to be the first Western intellectual to use the term 'Islamofascism' in 2001. He writes what he means by the term Islamofascism:

In my analysis, as originally put in print directly after the horror of September 11, 2001, Islamofascism refers to use of the faith of Islam as a cover for totalitarian ideology. This radical phenomenon is embodied among

4 Uri Friedman, 'The Coming War on "Radical Islam", The Atlantic, November 29, 2016, accessed November 7, 2017, https://www.theatlantic.com/international/archive/2016/11/trump -radical-islam $/ 508331 /$.

5 See, for example, search results for \#islamofascists on Twitter, accessed November 5, 2017, https://twitter.com/hashtag/islamofascists; The Facebook group, 'Death to Islamofascism ie. ISIS, the Muslim Brotherhood, CAIR \& HAMAS,' accessed November 5, 2017, https://www .facebook.com/pages/Death-to-Islamofascism-ie-ISIS-the-Muslim-Brotherhood-CAIR -HAMAS/1526665400890706; John Sargeant, 'IsIS and Clerical Fascism,' Huffington Post (UK), September 16, 2014, accessed November 7, 2017, http://www.huffingtonpost.co.uk/ john-sargeant/isis-and-clerical-fascism_b_5827364.html; Gordon Olivant, 'The Face of Evil: ISIs Demonstrates the Inhumanity of Islamofascism,' A Conservative's Musings on All things Political, February 10, 2015, accessed November 3, 2017, http://aconservativesmusings .com/2015/02/10/the-face-of-evil-isis-demonstrates-the-inhumanity-of-islamofascism/; and the website MarkHumphrys.com, which is dedicated to exposing the 'Islamofascism' of both right and left, accessed November 5, 2017. For the characterization of Hamas as fascist, see the historian Jeffrey Herf, 'Why they Fight: Hamas Too-Little-Known Fascist Charter,' The American Interest, August 1, 2014. Also, see Uriel Abulof, 'The Liberal Uncanny: ISIS is Fascist? (and So Are We?),' The Huffington Post, January 11, 2016, accessed October 10, 2017, http://www .huffingtonpost.com/uriel-abulof/the-liberal-uncanny-isis-_b_8934148.html. 
Sunni Muslims today by such fundamentalists as the Saudi-financed Wahhabis, the Pakistani jihadists known as Jama'atis, and the Egyptian Muslim Brotherhood. In the ranks of Shia Muslims, it is exemplified by Hezbollah in Lebanon and the clique around President Mahmoud Ahmadinejad in Iran. ${ }^{6}$

The most famous person to underscore the fascism and Islamism comparison was former US President George W. Bush. In 2006, Bush explicitly compared Islamist movements such as al-qāidah (al-Qaeda) with fascism: 'This nation is at war with Islamic fascists who will use any means to destroy those of us who love freedom, to hurt our nation. ${ }^{7}$ This statement was made after the United Kingdom announced it had foiled a plot to blow up airliners over the Atlantic.

In the same year that President Bush compared Islamism to fascism, the top us army official in the Middle East General John Abizaid, compared the rise of Islamist ideologies to the explosion of fascism in Europe in the 1920s and 1930s, which set the stage for World War Two. He suggested that confronting radical Islamists was an absolute necessity: 'If we don't have enough guts to confront this ideology today, we'll go through World War Three tomorrow.' Abizaid made his speech at Harvard University. Another military official, Colonel Dale C. Eikmeier, a strategic planner at the us Army War College's Center for Strategic Leadership, argued that Qutbism is a variant of 'Islamic-Fascism' and the 'War on Terrorism' was really also a war against 'Islamic-Fascists.9

Intellectuals such as Norman Podhoretz and Christopher Hitchens also used the term 'Islamofascism' to describe al-qāंidah and other jihadist groups.

6 Stephen Schwartz, "What Is "Islamofascism"? A History of the Word from the First Westerner to use it,' The Weekly Standard, August 16, 2006, accessed November 10, 2017, https://www .weeklystandard.com/stephen-schwartz/what-is-islamofascism.

7 George W. Bush, White House 2006, quoted in Peter Lentini, Neojihadism: Towards a New Understanding of Terrorism and Extremism? (Cheltenham: Edward Elgar Publishing, 2013), 140.

8 Reuters, 'Us general: Islamic Militancy Could Yield Third World,' Haaretz, November 18, 2006, accessed November 25, 2017, http://www.haaretz.com/news/us-general-islamic-militancy -could-yield-third-world-war-1.205399.

9 Qutbism is named after the radical, Egyptian Islamist Sayyid Qutb (1906-1966), who was a leading member of the Muslim Brotherhood and was killed in an Egyptian prison in 1966. Qutb inspired disciples such as Abdullah Azzam and Ayman al-Zawahiri. He argued that the 'near enemies' (e.g., secular Arab rulers) should be assassinated because they did not implement the Islamic law and allowed Arab societies to live in a state of jăhilīyah, or pagan barbarism which was ignorant of divine guidance. This Qutbian strategy was in contrast to al-Qaeda, which attacked the 'far enemy first' (e.g., the Soviet Union, the UsA, or the West). See Dale C. Eikmeier, 'An Ideology of Islamic-Fascism,' Parameters (Spring 2007): 85-97. 
Podhoretz warned that the West will need to fight a 'fourth world war' against the 'Islamofascists', ${ }^{10}$ while Hitchens defended 'Islamofascism' as a valid term and more than merely propaganda for the Bush regime. ${ }^{11}$ In the wake of the 9/11 terrorist attacks against the USA, Hitchens argued that al-qāidah represented a 'fascism with an Islamic face.' ${ }^{2}$ In 2007, the neo-conservative activist David Horowitz launched a series of lectures and protests on college campuses in the USA under the banner of 'Islamo-Fascism Awareness Week', which led to accusations of Islamophobia by some Muslim students and anti-racist groups. ${ }^{13}$

Yet, 'Islamofascist' discourse could be discerned as far back as 1956 when the United Kingdom's Prime Minister Antony Eden told us President Eisenhower that pan-Arab Egyptian leader Nasser was a 'Hitler' or 'Muslim Mussolini'. ${ }^{14}$ As Stanley Payne has characterized the Ba'athist regime as fascist and Sternhell argued that fascism was a union between ultra-nationalism and socialist revisionism, ${ }^{15}$ it was not a stretch for Eden to suggest that Nasser's pan-Arabism infused with socialism was a variant of fascism. Or, to the 1930s when the rise of fascism led to fears of a new wave of conquest akin to the early, missionary spirit of Islam. Karl Barth (1886-1968), a Swiss Protestant intellectual, argued in 1939 that it was impossible to 'understand National Socialism, unless we see it in fact as a new Islam, its myth as a new Allah, and Hitler as this new Allah's prophet.'16

$10 \quad$ Norman Podhoretz, World War IV: The Long Struggle Against Islamofascism (New York: Doubleday, 2007).

11 Christopher Hitchens, 'Defending Islamofascism: It's a valid term. Here's why,' Slate, October 22, 2007, accessedJuly 19, 2018, http://www.slate.com/articles/news_and_politics/ fighting_words/2007/10/defending_islamofascism.html.

12 Christopher Hitchens, 'Of Sin, the Left and Islamic Fascism,' The Nation, October 8, 2001.

13 See the website for 'Islamo-Fascism Awareness Week: Terrorism Awareness Project,' accessed November 15, 2017, http://www.terrorismawareness.org/islamo-fascism/49/a -students-guide-to-hosting-islamo-fascism-awareness-week/, or http://mediao.terroris mawareness.org/files/Islamo-Fascmism-Awareness-Week-Guide.html, accessed July 12, 2018.

14 Ollie Stone-Lee, 'Eden: A man under strain,' ввс News, July 21, 2006, accessed November 15, 2017, http://news.bbc.co.uk/2/hi/uk_news/politics/5193202.stm.

15 Stanley G. Payne, A History of Fascism, 1914-1945 (Madison, Wisconsin: The University of Wisconsin Press, 1995); Zeev Sternhell, Mario Sznajder and Maia Asheri, The Birth of Fascist Ideology: From Cultural Rebellion to Political Revolution (Princeton, NJ: Princeton University Press, 1995).

16 Karl Barth, The Church and the Political Problem of our Day (New York: Scribner, 1939), quoted in Reinhard Schulze, 'Islamofascism: Four Avenues to the Use of an Epithet,' Die Welt des Islams $5^{2}$ (2012): 315 . 
Pro-Fascist and pro-Nazi sentiments in the Arab world during World War Two have further led to accusations of 'Islamofascism', although recent scholarship uses more local sources and offers a more nuanced appraisal of proNazi collaboration in the Arab world. ${ }^{17}$ Historians have theorized about the involvement of individuals such as Grand Mufti Amin al-Husseini in Nazi crimes; the roots of Arab nationalist doctrine in German volkisch circles; the mimicry of Nazism in organizations such as the Iraqi al-Futuwwa ${ }^{18}$ and Antun Saadeh's Syrian Social Nationalist Party; and Arab public sympathies for Nazi anti-Semitism in the 1930s and 1940s. Yet, René Wildangel notes that although there were cases of Palestinian collaboration with Nazism in the 1930s and 1940s, the Arab Palestinian community was 'far from embracing the Islamofascism paradigm and its ideological foundations. ${ }^{19}$ Götz Nordbruch argues that Islamic traditions acted as a bulwark against National Socialist and Fascist propaganda in the Arab world in the 1930s and 1940s. ${ }^{20}$

\section{Islamism as Political Ideology}

Fascism and Islamism are modern political ideologies, but not cut from the same cloth. I do not aim to pin the fascist label on Islamists indiscriminately, but to assess the possibilities of comparing and contrasting Islamism and fascism as coherent political ideologies. I also highlight and analyze a four-fold typology of different discourses related to 'Islamofascism'.

There is a view among some scholars that ideologies are modern, secular, and anti-conservative; or the Marxist view that religious fundamentalists represent a form of 'false consciousness. ${ }^{21}$ From this aforementioned

17 Peter Wien, 'Coming to Terms with the Past: German Academia and Historical Relations between the Arab Lands and Nazi Germany,' International Journal of Middle East Studies 42, no. 2 (2010): 311-321; Peter Wien, Iraqi Arab Nationalism: Authoritarian, Totalitarian and Pro-Fascist Inclinations, 1932-1941 (Abingdon: Routledge, 2006); Stefan Wild, 'National Socialism in the Arab East between 1933 and 1939,' Die Welt des Islams 25, no. 1/4 (1985): 126-173.

18 A type of Hitler Youth-style, pan-Arab, and fascist movement, which existed in Iraq in the 1930s and 1940s. They sent a delegate to the Nuremberg Nazi Party rally and once hosted the Hitler Youth leader Baldur von Schirach.

19 René Wildangel, "The Invention of "Islamofascism": Nazi Propaganda to the Arab World and Perceptions from Palestine,' Die Welt des Islams $5^{2}$ (2012): $5^{26}$.

20 Götz Nordbruch, 'Islam as a "Giant Progressive Leap": Religious Critiques of Fascism and National Socialism, 1933-1945,' Die Welt des Islams 52 (2012): 499-525.

21 Michaelle L. Bowers, 'The Secular Bias in Ideology Studies and the Case of Islamism,' Journal of Political Ideologies 10, no. 1 (2005): 75-93. 
perspective, Islamism does not qualify as a political ideology. Yet, following Roger Eatwell, I argue that a political ideology is 'a relatively coherent set of empirical and normative beliefs and thought, focusing on the problems of human nature, the process of history, and socio-political arrangements. ${ }^{22}$ Eatwell also points out that an ideology acts as 'either a stabilizing or radical force', while it is a Weberian 'ideal type', which is a useful heuristic device. ${ }^{23}$

Using Eatwell's definition of political ideology, both fascism and Islamism are political ideologies. ${ }^{24}$ Both ideologies propose ideal socio-political arrangements (for example, the shari ${ }^{-} a h$-based state and Caliphate for Islamists, or the secular, totalitarian state with a corporatist orientation for fascists); both envision processes of history consisting of struggle, violence, and war in order to attain a pan-European empire (fascists), or, for Islamists a Caliphate through the path of ğihäd (jihad ) ${ }^{25}$ by overthrowing secular governments in the Muslim world, re-conquering lost Muslim territories (for example, Palestine from Israel, Chechnya from Russia, or Xinjiang from China), and putting the entire realm of dar al-Harb [the abode of war] under the control of dar-alIslam [the abode of peace or submission]. ${ }^{26}$ Both fascists and Islamists opine about the problem of human nature with fascists less optimistic about putting an end to a history of national or racial struggle. Ernst Jünger (1895-1998), a conservative revolutionary thinker that sympathized with fascism, declared

22 Roger Eatwell, 'Introduction: What Are Political Ideologies?' in Contemporary Political Ideologies, ed. Roger Eatwell and Anthony Wright (New York: Continuum, 2003), 17.

23 Eatwell, 'Introduction,' 17.

24 For a defense of Islamism as a political ideology, see Bowers, 'The Secular Bias in Ideology Studies and the Case of Islamism.'

25 Jihad includes 'lesser jihad' through the path of violent struggle against the enemies of Islam, or the 'greater jihad', which connotes becoming a better Muslim in the path of God. The 'lesser jihad' is the primary meaning of jihad and connotes a struggle against the enemies of Islam. Jihad is not one of the five pillars of Islam, but central to radical Islamists, especially 'takfiri' Islamists. 'It is an Islam willing to die and fight by the sword,' as well as purge the world of 'everything that is not fully in line with God's teachings or the prophet's life.' See Jarret M. Brachman, Global Jihadism: Theory and Practice (Routledge: New York, 2009), 5 .

26 Some Islamists such as Abu Jandal al-Azdi of Al-Qa'ida on the Arabian Peninsula differentiate between the original abode of unbelief (dar al-kufr al-asli), which includes countries that have never lived under Muslim rule (e.g., the UsA or most of Europe); the unusual abode of unbelief (dar alkufral-tari'), areas that were once under Muslim rule (e.g., Spain and Portugal); and the abode of apostasy (dar al-ridda), denoting a separate category of dar al-kufr al-tari' that was once dar al-Islam but has left this realm because of its application of 'man-made laws' (e.g., secular Arab regimes). See Joas Wagemakers, 'Al-Qa'ida's Editor: Abu Jandal al-Azdi's Online Jihadi Activism,' Politics, Religion and Ideology 12, no. 4 (2011): 366 . 
his love of war: 'War, father of all things, is also ours; he has hammered us, chiseled and tempered us into what we are. ${ }^{27}$ Islamists argue that humans are tempted by evil and often justify violence, but following the path of the 'Qur'an as the constitution, ${ }^{28}$ they will create better human beings and build a universal order wedded to social justice and the ummah. Hassan al-Banna, the former leader of the Muslim Brotherhood, declared his movement's totalitarian goals in 1934: 'To establish Allah's sovereignty over the world. To guide all of humanity to the precepts of Islam (without which mankind cannot attain happiness).'29

Michael Freeden points out that political ideologies contain core, adjacent, and peripheral concepts. ${ }^{30}$ What is the core of fascism? Extreme nationalism or ultra-nationalism? The cult of the leader? The union of socialist and nationalist ideals? For Islamism, is the core al-qur'ann as the constitution? Or, the model of the first Islamic state formed by Muhammad in Medina? Or, the first four rightly guided caliphs (al-Khulafäu ar-Räshidūn - Abu Bakr, Umar, Uthman ibn Affan, and Ali)? Or, conquest of the world and restoration of Muslim geopolitical greatness? Or, how about tawhid [the oneness of God], Islam din wa dawla [Islam is a religion and state or political power], al-hakmiyya lil-allah [sovereignty belongs to God], or the ummah [the Muslim community of believers]?31 How about adjacent concepts for Islamism? Jāhilìyah [pre-Islamic barbarism or ignorance], jihad [struggle], takfir [heresy], shura [consultation], ta'adul,

27 Ernst Jünger quoted in Fascism, ed. Roger Griffin (Oxford: Oxford University Press, 1995), 109 .

28 The slogan of Islamists, including the Muslim Brotherhood. In 2012, its leader and future Egyptian President Mohamed Morsi stated the following in an election speech to students at Cairo University, which is the motto of the Muslim Brotherhood: 'The Koran is our constitution, the Prophet is our leader, jihad is our path and death in the name of Allah is our goal.' See Ayaan Hirsi Ali, 'The Quran Is Our Law; Jihad Is Our Way,' The Wall Street Journal, February 18, 2011, accessed November 23, 2017, http://online.wsj.com/ articles/SB10001424052748704132204576136590964621006. See also the Hamas Covenant, where the same motto is repeated, as Hamas is an offshoot of the Muslim Brotherhood. For the Hamas Covenant (1988), see 'The Covenant of the Islamic Resistance Movement,' The Avalon Project: Documents in Law, History and Diplomacy, August 18, 1988, accessed October 15, 2016, http://avalon.law.yale.edu/2oth_century/hamas.asp.

Hassan al-Banna, To What Do We Invite Humanity? (Cairo, n.p., 1934), quoted in: Andrea Mura, 'A Genealogical Inquiry into Early Islamism: The Discourse of Hassan al-Banna,' Journal of Political Ideologies 17, no. 1 (2012): 71.

$30 \quad$ Michael Freeden, Ideologies and Political Theory: A Conceptual Approach (Oxford: Oxford University Press, 1998), 47-138.

Bowers, 'The Secular Bias in Ideology Studies and the Case of Islamism,' 86. 
musawa [the equality of Muslims], or 'adala [justice] $?^{32}$ Nationalism is arguably a peripheral concept for Islamists because nation-states are Western constructs and nations contradict and divide the pan-Islamic ideal of the ummah.

Teun van Dijk argues that political ideologies entail ideological polarization between ingroups and outgroups, while they tend to emphasize their own good deeds and properties in comparison to the bad deeds and properties of their enemies. ${ }^{33}$ In this respect, both fascists and Islamists engage in extreme ideological polarization against liberal and secular societies respectively, while scapegoating 'enemies' of the nation or faith, whether Jews or 'rootless cosmopolitans' in fascism or secular rulers, Westerners, or 'enemy occupiers' of Muslim lands for Islamists. Fascists and Islamists legitimize their negative actions, including genocide or suicide bombings, as 'cleansing' for the nation or Islam, while their opponents are demonised as sub-humans, godless communists, or murderous Zionists.

The growing importance of Islamists and the violence of jihadists towards their political opponents in the international arena requires us to pause for reflection. Like the secular fascists of the interwar years, Islamists are anti-liberal, anti-communist, anti-Semitic, totalitarian, patriarchal, violent, expansionist, and revolutionary. Are contemporary Islamists akin to the fascists of the interwar years in Europe or modern neo-fascists? And it begs these questions: What is fascism? What is Islamism? Will the comparison between Islamism and fascism add to our analytical confusion? Is the Islamism-fascism comparison a rhetorical trope used by the USA and the West in order to indoctrinate its citizens, heighten Islamophobia, and exaggerate the threat of Islamism, thus justifying preemptive wars and other violations of sovereignty against the Muslim world ${ }^{34}$ Or, is it valid to compare and contrast Islamism and fascism?

\section{Four Camps}

I identified four camps in respect of the comparison between Islamism and fascism: (1) 'Thou shall not compare'; (2) 'Islamofascism'; (3) 'Islamofascism as epithet'; and (4) 'Dare to compare'. The first position insists that we cannot

32 Ibid., 87 .

33 Teun A. van Dijk, 'Ideology and discourse analysis,' Journal of Political Ideologies 11, no. 2 (2006): 139 .

34 Moshe Zuckerman, “Islamofascism”: Remarks on a Current Ideologeme,' Die Welt des Islams $5^{2}$ (2012): 351-369; Stefan Wild, “Islamofascism?": Introduction,' Die Welt des Islams $5^{2}(2012): 233$. 
compare Islamism and fascism. Two major proponents of this camp are the academics Juan Cole and Judith Butler. ${ }^{35}$ The second position concludes that Islamism is a variant of fascism. Proponents of this camp include Hamed Abdel-Samad, Jeffrey Herf, Christopher Hitchens, Lee Jenkins, Stephen Schwartz, Mohamed Sifaoui, Norman Podhoretz, Daniel Pipes, Francis Fukuyama, Amir Taheri, David Meir-Levi, and Matthias Küntzel. ${ }^{36}$ The third position argues that Islamofascism is an epithet used to discredit Islamists and justify us or Western 'neo-colonial' practices. ${ }^{37} \mathrm{Key}$ proponents of this position include Reinhard Schulze, Moshe Zuckerman, and Alain de Benoist. ${ }^{38}$ The fourth position dares to compare Islamism and fascism as political ideologies, but concludes that while there are similarities in terms of practices and some goals of the two ideologies, Islamism is a distinctive totalitarian ideology. Key proponents of this position include Martin Kramer, Walter Laqueur, and Jeffrey Bale. ${ }^{39}$ I identify with the insights of the 'Dare to compare' camp.

It should be noted that camps one ('Thou shall not compare') and three ('Islamofascism as epithet') share important similarities, while they might be interpreted by some as not entirely separate categories. That is, many of those that reject any and all comparisons between Islamism and fascism do so because they believe that such comparisons are propagandistic devices designed to demonise Islamism. Yet, I have retained the two camps because the 'Islamofascism as epithet' camp is more cynical and overtly political than the 'Thou shall not compare' camp. Moreover, the 'Thou shall not compare' camp is used to demonstrate that, in most cases, it is a mistaken position to undermine all

35 Martin Kramer, 'Islamism and Fascism: Dare to Compare,' Sandbox, September 20, 2006, accessed September 13, 2017, http://www.martinkramer.org/sandbox/2006/o9/ islamism-and-fascism-dare-to-compare/.

36 Herf, 'Why they Fight'; Hitchens, 'Defending Islamofascism,' 7; Eric Boehlert, 'Islamism is Fascism: An Interview with Daniel Pipes,' Slate.com, November 9, 2001, published at danielpipes.org, accessed July 20, 2018, http://www.danielpipes.org/81/islamism-is-fascism?; Francis Fukuyama, 'Has History Started Again?' Policy 18, no. 2 (Winter 2002): 3-7; Amir Taheri, 'Fascism in Muslim Countries,' American Foreign Policy Interests 26 (2004): 21-30; David Meir-Levi, Upside Down: The Roots of Palestinian Fascism and the Myth of Israeli Aggression (New York: Encounter Books, 2007); and Matthias Küntzel, Jihad and Jew-Hatred: Islamism, Nazism and the Roots of 9-11 (New York: Telos Press Publishing, 2007).

37 Wild, 'National Socialism in the Arab East between 1933 and 1939,' 30.

38 Zuckerman, 'Islamofascism'; Wild, 'National Socialism in the Arab East between 1933 and 1939'; and Schulze, 'Islamofascism.'

39 See Kramer, 'Islamism and Fascism'; Jeffrey M. Bale, 'Islamism and Totalitarianism,' Totalitarian Movements and Political Religions 10, no. 2 (2009): 96; and Walter Laqueur, 'Fascism in the Twenty-First Century?' Society 44, no. 4 (May/June 2007): 48-53. 
attempts at comparisons between Islamism and fascism. In refusing all comparisons between the two political ideologies, we fail to see possible similarities between Islamism and fascism.

In addition, we might also classify the different discourses in relation to the fascism-Islamism comparison based on disciplines such as journalism, sociology, political science, law, military affairs, or philosophy. Each of these different disciplines might have different criteria for how to evaluate the fascism-Islamism comparison. This might be a fruitful avenue for future research. Pete Lentini has suggested that there is a gap between academic specialists and non-academic perspectives on the fascism-Islamism comparison: 'Although the Islamo-fascism appellation has been popular among politicians and pundits, few scholars of either Islam or fascism appeared willing to use the term. ${ }^{\prime 40}$

At this point, I review the discourses of the four camps. Juan Cole is a proponent of the 'Thou shall not compare' camp. A Professor of History at the University of Michigan, Cole insisted that going to Saudi Arabia is 'kind of like going to Amish country in the United States. ${ }^{41}$ The Saudis are conservative and perhaps Islamist, but certainly not fascist. Moreover, the Saudis are not really violent, which is certainly not true both at home and abroad. ${ }^{42}$ The ideological justification for the Saudi state is provided by Muhammad ibn 'Abd al-Wahhab (1703-92), the founder of Wahhabism. As Stephen Schwartz notes, the Wahhabis 'represent a violent, exclusionary, and fundamentalist reactionary utopia dedicated to reviving outward forms of Muslim life as it was lived centuries ago, and claim to reform Islam by purging it of everything it has assimilated or contributed to world culture since then. ${ }^{43}$ As a result of its focus on takfir [excommunication of unbelievers from the Muslim community], Wahhabism is 'radical rather than conservative, and it is destructive of tradition. ${ }^{44}$ Thus, it is no accident that the Wahhabis 'have earned a reputation for such unrestrained

$40 \quad$ Lentini, Neojihadism, 145.

41 Juan Cole, quoted in Kramer, 'Islamism and Fascism.'

42 For Saudi Arabia's authoritarian violence at home, see Human Rights Watch, 'World Report 2013: Saudi Arabia,' accessed September 22, 2017, http://www.hrw.org/world-report/ 2013/country-chapters/saudi-arabia. For the Saudi regime's sponsoring of terrorism abroad, see Daniel Byman, Deadly Connections: States that Sponsor Terrorism (Cambridge: Cambridge University Press, 2005); and Stephen Schwartz, The Two Faces of Islam: Saudi Fundamentalism and Its Role in Terrorism (New York: Anchor Books, 2003).

43 Stephen Schwartz, 'The Terrorist War against Islam: Clarifying Academic Confusions,' Academic Questions 24, no. 59 (2011): 62.

44 Schwartz, 'The Terrorist War against Islam,' 62. 
bloodshed against Muslims that they are feared and execrated by ordinary believers throughout Muslim lands. ${ }^{25}$

Judith Butler, another prominent academic, once told an audience at Berkeley that Islamist terrorist groups such as Hamas and Hezbollah are 'social movements that are part of the global left.'46 Both Butler and Cole fail to see the 'reactionary' nature of the Islamist project in the Gramscian sense: ${ }^{47}$ Its rejection of secularism, democracy, women's rights, and equality, and its violence towards non-Muslims, secular Muslims, 'apostate Muslims', and Shi'a Muslims.

Cole also denounced the 'lazy conflation of Muslim fundamentalist movements with fascism. ${ }^{48} \mathrm{He}$ noted that 'most fascism in the Middle East has been secular in character, as with Saddam Hussein's Ba'ath Party. ${ }^{\prime 9}$ In this respect, Cole had some support from a major historian of fascism. Stanley Payne pointed out that Saddam Hussein's regime (1979-2003) met most of the prerequisites of fascism, ${ }^{50}$ although the regime was Ba'athist in ideological inspiration, a mixture of pan-Arabism and socialism. Yet, while Cole linked Saddam Hussein's regime with fascism, he was rather quick to dismiss the comparison between Islamist, Wahhabi Saudi Arabia and fascism.

The second camp is 'Islamofascism'. Stephen Schwartz is a representative of this camp. He argues that Islamofascism is not a polemical term, but has a specific analytical meaning in relation to radical Islamists with a totalitarian worldview: 'Islamofascism is neither a loose nor an improvised concept. It should be employed sparingly and precisely. The indicated movements should be treated as Islamofascist, first, because of their congruence with the defining characteristics of classic fascism, especially in its most historically-significant form - German National Socialism. ${ }^{51}$ Given that the first explicitly fascist movement was created in Italy in 1919 and fascists first came to power in Italy in 1922, it is questionable whether National Socialism was the 'most historically-significant' type of fascism. Some historians of fascism such as Sternhell refuse to classify National Socialism as fascism because of the regime's obsession

\footnotetext{
45 Ibid., 71.

46 Judith Butler, quoted in Kramer, 'Islamism and Fascism.'

47 Stephen Gill has labelled Islamist movements as 'reactionary forces' pitted against proneo-liberal hegemonic, counter-hegemonic, and progressive forces. See Stephen Gill, Power and Resistance in the New World Order, $2^{\text {nd }}$ ed. (Basingstoke, U K: Palgrave-Mac Millan, 2008), 256-258.

48 Juan Cole, quoted in Kramer 'Islamism and Fascism.'

49 Ibid

$50 \quad$ Payne, $A$ History of Fascism, $5^{16}$.

51 Schwartz, 'The Terrorist War against Islam.'
} 
with biological racism. ${ }^{52}$ In any case, Schwartz also notes that Islamofascism and fascism in interwar Europe share these characteristics: radical, global in scope, totalitarian, imperialistic, paramilitary in organizational style, and a penchant for gratuitous terrorism and violence. ${ }^{53}$

The British-Britain journalist and author Christopher Hitchens (1949-2011) saw similarities between Islamists such as al-Qaeda and fascists. In a 2007 piece in Slate, Hitchens elaborated on the fascism-Islamism comparison: Both movements valorize violence and death; are hostile to modernity; obsessed with humiliation and revenge; anti-Semitic; stress leader worship; promote sexual repression; despise art and literature; and are populist. ${ }^{54}$

Another representative of the 'Islamofascism' camp is the journalist Lee Jenkins. Writing in 2013, Jenkins exhorted his readers to do the following: 'Get past the headlines, the symbols and sound bites and you find striking similarities between the extremist ideologies of 1930's European Fascism, and today's Jihadist interpretation of Islam. ${ }^{, 5}$ He added that 'Islamism is our generation's fascism,' while fascism and Islamism are united by the following traits: (1) glorification of violence; (2) hyper-social conservatism; (3) strength through unity; (4) anti-capitalism; (5) imperialist foreign policy and a yearning to return to a Golden Era; (5) rampant sexism; (6) brutal homophobia; and (7) nihilism and insistence on ideological purity.

Another exponent of the 'Islamofascism' position is Mohamed Sifaoui, an Algerian-French journalist. Sifaoui became famous for his 2003 book Mes 'frères' assassins: Comment j'ai infiltré une cellule d'Al-Qaïda [My assassin 'brothers': How I infiltrated an al-Qaeda cell]. In a 2008 interview in The Middle East Quarterly, Sifaoui stated that he considers 'Islamism to Be Fascism. ${ }^{56} \mathrm{He}$ argues that the uniting characteristic between Islamism and fascism is 'their will to exterminate the Jews. ${ }^{57}$ He posits that Islamism is perhaps even more anti-Semitic than Nazism, noting that for Islamists, 'the end of the world could only occur when there are no Jews left on earth. ${ }^{58}$ It should be noted that Sifaoui makes no distinction between Fascism and Nazism. Yet, there were 230 Italian Jewish Fascists that took part in the March on Rome and Jews were disproportionately

\footnotetext{
$5^{2}$ Sternhell, Sznajder and Asheri, The Birth of Fascist Ideology, 4-5.

53 Schwartz, 'The Terrorist War against Islam.'

54 Hitchens, 'Defending Islamofascism.'

55 Lee Jenkins, 'Islamism Is Our Generation's Fascism', The Backbencher, July 25, 2013, accessed September 18, 2017, http://thebackbencher.co.uk/islamism-is-our-generations-fascism/.

56 Mohamed Sifaoui, 'I Consider Islamism to Be Fascism', Middle East Quarterly (Spring 2008): 13-17.

57 Sifaoui, 'I Consider Islamism to Be Fascism,' $13-17$

$5^{8}$ Ibid.
} 
represented in the Fascist Party until the implementation of the race laws in 1938 (i.e., about one-third of Jewish adults in the mid-1930s). ${ }^{59}$ Georges Valois, the leader of the French fascist party Le Faisceau, invited Jews into his movement. However, the Nazis did not have Jewish members in the party and they had the genuine 'will to exterminate the Jews.'

The third camp is 'Islamofascism as epithet'. It is best summarized by Reinhard Schulze's characterization of 'Islamofascism' as an 'epithet' and 'strategy' used by the USA and the West in order to demonise the Muslim world as a prelude to controlling it: 'first identifying Islam as essentially fascist, next generalizing Arab or Muslim positive statements on Hitler and/or Mussolini, and finally pointing to certain states in the Muslim world that supposedly followed the fascist model (here Turkey and Iran). ${ }^{\prime 60}$ Geert Wilders, the anti-immigrant leader of the Partij voor de Vrijheid [PVv; Party for Freedom] in the Netherlands, also highlighted the 'Islamofascism as epithet' discourse in a letter to the daily De Volkskrant published on August 8, 2007: 'The core of the problem is fascist Islam, the sick ideology of Allah and Mohammed as laid down in the Islamic Mein Kampf: The Koran. ${ }^{61}$ Schulze also explains that French intellectual Bernard-Henri Lévy uses the 'strategy' of 'Islamofascism as epithet.' Although Lévy makes a distinction between Islam and Islamism, he argues that 'radical Islam is fascism' and there is 'a rhetorical and textual continuity between the old European fascism and the new Islamist fascism. ${ }^{\text {' } 2}$

In 2014, the leader of the French nouvelle droite [New Right] lamented the political uses of fascism and anti-fascism, while suggesting that Islamofascism is a mere political creation used to discredit political opponents: 'Recently, the locutions "red fascism" or even "Islamofascism" have been invented. These conflicting interpretations, these absolutely meaningless verbal formulations, show that the debate about fascism today is at level zero of the thought process.' ${ }^{63}$ Note that de Benoist does not dare to compare Islamism and fascism because it is his view that fascism has many competing definitions and it was largely a product of the crises of the interwar years. Moreover, de Benoist is adamant that 'Islamofascism' is a political tool of the Anglo-American neo-conservative establishment. Also, it is interesting to note that Griffin, Mammone, Copsey,

\footnotetext{
59 Tamir Bar-On, Where Have All The Fascists Gone? (Aldershot: Ashgate, 2007), 2.

6o Schulze, 'Islamofascism,' 332.

61 Ibid., 292.

62 Bernard-Henri Lévy, The Spectator, October 14, 2006, quoted in Schulze, 'Islamofascism,' 298.

63 Alain de Benoist in Arthur Versluis, 'A Conversation with Alain de Benoist', Journal for the Study of Radicalism 8, no. 2 (2014): 81.
} 
and Bar-On have accused de Benoist's nouvelle droite movement of attempting to resurrect a politically correct neo-fascism suited for anti-fascist times. ${ }^{64}$

The fourth camp is 'Dare to compare'. It is represented by Walter Laqueur, a historian of fascism. Laqueur notes that 'Islamic fascism', like Islamophobia and anti-Semitism, are 'imprecise terms we could well do without but it is doubtful whether they can be removed from our political lexicon.65 Laqueur takes the Islamism and fascism comparison seriously, but ultimately concludes that while the two ideologies share similarities, they are two distinctive political ideologies. ${ }^{66} \mathrm{He}$ points out that radical Islamists have 'some striking parallels with fascism - the populism, the belief that they, are the possessors of the sole truth ("Islam is the answer"), the opposition to democracy and liberalism, anti-Semitism and, in general, its aggressive and expansionist character. ${ }^{\prime} 7$ Laqueur adds that Islam, like fascism, is for the Islamists not merely a religion, but also 'a comprehensive political and social order from which no deviation is permitted. ${ }^{68}$

Laqueur, however, sees differences between fascism and Islamism. In the first place, Islamism lacks a single Fuehrer or Duce, ${ }^{69}$ although there is a spiritual leader or collective leadership (for example, the Guardian Council in the Islamic Republic of Iran). This is contradicted by Jeffrey Bale and Mehdi Mozaffari, who both claim that Islamism is 'totalitarian' because it is universal, based on divine truth, and seeks to conquer all spaces in civil society through the erection of the Islamic state. ${ }^{70}$ Second, fascism was 'a European phenomenon, ${ }^{71}$ whereas Islamism is largely confined but not strictly located in the Muslim world. Third, fascism presumably ended in 1945, whereas Islamism is undergoing a revival. Fourth, 'Hitler and Mussolini did not engage in Jihad and did not want to impose the sharia. ${ }^{72}$ Fifth, the Islamist movements have a

64 Tamir Bar-On, 'A Response to Alain de Benoist,' Journal for the Study of Radicalism 8, no. 2 (2014): 123-168.

65 Walter Laqueur, 'The Origins of Fascism: Islamic Fascism, Islamophobia, Antisemitism,' UOPBlog, 25 October 2006, accessed September 8, 2017, http://blog.oup.com/2006/10/ the_origins_of_2/.

66 Laqueur, 'Fascism in the Twenty-First Century?' $48-53$.

67 Ibid., $5^{2}$.

68 Ibid.

69 Ibid.

70 Bale, 'Islamism and Totalitarianism', 73-96; Mehdi Mozaffari, 'What is Islamism? History and Definition of a Concept,' Totalitarian Movements and Political Religions 8, no. 1 (March 2007): 22.

71 Mozaffari, 'What is Islamism?' 22.

72 Laqueur, 'Fascism in the Twenty-First Century?' $5^{2}$. 
different ideology with competing visions of ideal political structures from the fascists and do not call themselves fascist. ${ }^{73}$ Pol Pot's regime in Cambodia was genocidal and left-wing rather than fascist.

Similarly, Jeffrey Bale is a milder proponent of the 'Dare to compare' camp. Although Bale sees Islamism as a form of totalitarianism, he uses the Israeli historian of fascism Zeev Sternhell ${ }^{74}$ to point out that since fascism is a 'secular revolutionary ideology combining radical nationalism and non-Marxist socialism' and 'Islamism's principal enemy is Western secularism,' it would be 'absurd' to 'characterise Islamism as a form of fascism. ${ }^{75}$

I reject the claims made by the 'Islamofascism', 'Islamofascism as epithet' and 'Thou shall not compare' camps. Cole exhibits what Jeffrey Bale calls 'Islamism apologism', thus being too sympathetic to his object of study and failing to see the totalitarian, anti-democratic, and violent aspects of Islamism and rejecting any comparison with fascism. ${ }^{76}$ The 'Islamofascism' camp is too quick to judge Islamism as a form of fascism and obscures important differences between fascists and Islamists. The 'Islamofascism as epithet' camp lacks academic seriousness because it is a term of abuse. ${ }^{77}$ This camp does not tell us much about the aims or substantive content of either Islamism or fascism.

I support the 'Dare to compare' camp because it takes seriously the claim that we should compare Islamism and fascism. Yet, unlike the 'Islamofascism' camp, this position does not conclude that Islamism is a form of fascism. Islamism and fascism can and should be compared as political ideologies, but Islamism is not fascism but rather a distinctive political ideology. Islamism shares with Fascism, Nazism, Stalinism, and Maoism the aim of totalitarianism. Few in the 'Islamofascism' camp are comprehensive in their comparison of Islamism and fascism..$^{78}$ Unfortunately, few scholars have meticulously attempted to seriously compare and contrast Islamism and fascism. Clerical

73 Ibid., $5^{2}$.

74 See, for example, Sternhell, Sznajder and Asheri, The Birth of Fascist Ideology.

75 Bale, 'Islamism and Totalitarianism,' 96.

76 Ibid., $73^{-79}$.

77 A. James Gregor, The Search for Neofascism: The Use and Abuse of Social Science (Cambridge: Cambridge University Press, 2006), 166-196.

78 An exception is Amir Taheri's comparison of the Islamic Republic of Iran with Umberto Eco's notion of 'Ur-fascism' (or 'eternal fascism'). See Taheri, 'Fascism in Muslim Countries,' 21-30. Taheri's conclusion is that the Islamic Republic of Iran is fascist and meets almost all of Eco's characteristics of 'Ur-fascism'. See Umberto Eco, 'Eternal Fascism: Fourteen Ways of Looking at a Blackshirt,' New York Review of Books, 22 June 1995: 12-15. 
fascism is the closest ideologically to Islamism. In short, Islamism does not equal fascism, but Islamism is a form of totalitarianism with a global vocation. ${ }^{79}$

\section{What is Fascism?}

In order to assess the Islamism-fascism comparison properly, it will be necessary to review the numerous definitions of fascism and Islamism. I begin with defining fascism. Gilbert Allardyce suggested that it was so difficult to define fascism that we should give up on defining it. ${ }^{80}$ A.J. Gregor has lamented that fascism has become a term of abuse, as well as increasingly a meaningless term indiscriminately applied to all political forces on the right. ${ }^{81}$ Against the claims of most historians of fascism, Gregor insists that ideologically diverse regimes such as the Stalinist Soviet Union, Maoist China, and Fascist Italy were united by fascist-like characteristics. ${ }^{82}$

Fascism is simultaneously an ideology, movement, political party, or regime in power. Renzo de Felice insisted that 'movement fascism' in Italy was more revolutionary, populist, anti-Semitic, and corporatist than 'regime fascism'. ${ }^{83}$ Gregor argues that fascist intellectuals such as Giovanni Gentile (1875-1944), Alfredo Rocco (1875-1935), Ugo Spirito (1896-1979), Sergio Panunzio (1886-1944), Enrico Corradini (1865-1931), Camillo Pellizzi (1896-1979), or Carlo Costamagna (1881-1965) were as intellectually coherent as their liberal or socialist counterparts. ${ }^{84}$ Gentile could view Fascism's intensity as akin to Catholicism because it was based on 'religious' fervor and lasted one's entire life; Fascism was 'a party, a political doctrine' and 'above all a total conception of life,' thus merging the individual, society, and state in a new, totalitarian framework. ${ }^{85}$ Studying fascist intellectuals such as Gentile and others, Gregor insisted: 'However Fascism is judged by history, the movement, the revolution, and the regime itself had, at their disposal, as talented and moral a cadre of

\footnotetext{
79 See Bale, 'Islamism and Totalitarianism,' 73-96; Mozaffari, 'What is Islamism?' 17-33.

8o Gilbert Allardyce, 'What Fascism is not: Thoughts on the Deflation of a Concept,' The American Historical Review 84, no. 2 (April 1979): 367-388.

81 Gregor, The Search for Neofascism, $15^{-16}$.

82 See A. James Gregor, The Faces of Janus: Marxism and Fascism in the Twentieth Century (New Haven, Ст: Yale University Press, 2000).

83 Renzo de Felice, Fascism: An Informal Introduction to its Theory and Practice (third edition) (New Brunswick, New Jersey: Transaction Publishers, 2009), 13-14.

84 A. James Gregor, Mussolini's Intellectuals: Fascist Social and Political Thought (Princeton, New Jersey: Princeton University Press, 2004), 17.

85 Giovanni Gentile quoted in Griffin, Fascism, 23, 54.
} 
intellectuals as any found in the ranks of revolutionary Marxism or traditional liberalism.' ${ }^{86}$

Unlike Islamism which contains a definitive 'bible' (i.e., the 'Qur'an as the constitution'), Roger Eatwell pointed out that fascism does not have its 'bible' or definitive text. ${ }^{87}$ Benito Mussolini (1883-1945), Adolf Hitler (1889-1945), Georges Valois (1878-1942), Corneliu Zelea Codreanu (1899-1938), and José Antonio Primo de Rivera (1903-1936) were all fascist ideologues and politicians, but we cannot point to one defining text uniting all fascists. Zeev Sternhell argued in an Israeli court that 'there is no clear and unequivocal definition of a fascist movement, and that no movement has all the components of the definition. ${ }^{88}$ French historians Milza and Berstein agreed with Sternhell and argue that 'no universally accepted definition of the fascist phenomenon exists, no consensus, no matter how slight, as to its range, its ideological origins, or the modalities of action which characterize it.' ${ }^{\prime 8}$ George Mosse, an early scholar of fascism, 'displayed a reluctance to formulate an illuminating shorthand definition' of fascism. ${ }^{90}$ Renzo de Felice concluded that no general definition of fascism could exist because every fascist regime was unique. ${ }^{91}$ Sternhell argued that Nazi Germany was too extreme in its biological racism to be considered fascist. ${ }^{92}$

I now provide various definitions of fascism, which I call minimalist and maximalist. Minimalist definitions of fascism attempt to incorporate all fascist ideologues, movements, political parties, and regimes under the ambit of one universal definition that applies to all of them. Examples of minimalist definitions of fascism include Roger Griffin's definition:'Fascism is a genus of political ideology whose mythic core in its various permutations is a palingenetic

86 Gregor, The Faces of Janus, 17.

87 Roger Eatwell, 'Reflections on Fascism and Religion,' Totalitarian Movements and Political Religions 4, no. 3 (2003): 145-166.

88 Zeev Sternhell, quoted in Nir Hasson, 'Jerusalem Court Starts Debating Meaning of Fascism as Im Tirtzu Sues Activists,' Haaretz.com, February 12, 2012, accessed September 18, 2017, http://www.haaretz.com/print-edition/news/jerusalem-court-starts-debating -meaning-of-fascism-as-im-tirtzu-sues-activists-1.412357.

89 Pierre Milza and Serge Berstein, Dictionnaire historique des fascismes et du nazisme (Bruxelles: Éditions Complexe, 1992), 7.

$90 \quad$ Roger Griffin, 'Studying Fascism in a Postfascist Age: From New Consensus to New Wave?' Fascism: Journal of Comparative Fascist Studies 1 (2012): 4, accessed July 19, 2018, doi: 10.1163/221162512X623601.

91 Christina Wieland, The Fascist State of Mind and the Manufacturing of Masculinity: A Psychoanalytic Approach (Routledge: New York, 2015), 13.

92 Sternhell, Sznajder and Asheri, The Birth of Fascist Ideology. 
form of populist ultra-nationalism. ${ }^{\prime 93}$ By palingenesis, Griffin means that fascists were obsessed with national decadence and saw their political project as one of national rebirth as a reaction to multiple crises of the interwar years. So, for example, a leading Nazi and head of the sA Hermann Goering, declared that with the rise of the Nazis to power, 'the German people has arisen and Germany will be healthy.'94 Griffin also insists that a 'new consensus' has emerged in respect of fascist studies related to a revolutionary form of ultranationalism that attempts to realize the dream of a regenerated nation. ${ }^{95}$ A.J. Gregor argued that fascism is a dictatorship based on 'reactive developmental nationalism', which seeks to sustain and secure 'the sovereign independence and international status of the revolutionary community. ${ }^{96}$ Another minimalist definition was offered by Roger Eatwell: 'An ideology that strives to forge social rebirth based on a holistic-national radical Third Way, though in practice fascism has tended to stress style, especially action and the charismatic leader, more than a detailed programme, and to engage in a Manichean demonisation of its enemies. ${ }^{97}$

Zeev Sternhell also proposed a minimalist definition of fascism. He posited that fascism was a combination of ultra-nationalism and a revision of Marxist socialism. ${ }^{98}$ Sternhell argued that the fascist synthesis was first created in France and combined Boulangisme [a populist movement led by Georges Boulanger who almost succeeded in his coup d'état in 1889], revolutionary syndicalism in the mould of George Sorel (which included Italian influences), and Cercle Proudhon's synthesis inspired by Georges Valois and Edouard Berth. In short, the fascist synthesis included revolutionary ultra-nationalists, renegade Marxists, and radical syndicalists. Sternhell's position was echoed by left-wing activists such as Henri de Man in Belgium and an early French fascist, Georges Valois, who argued that nationalism + socialism $=$ fascism. ${ }^{99}$

Maximalist definitions of fascism have been proposed by J.J. Linz (eighteen characteristics), Emilio Gentile (sixteen characteristics), Stanley Payne

93 Griffin, 'Studying Fascism in a Postfascist Age,' 5 .

94 Hermann Goering quoted in Griffin, Fascism, 133.

95 Roger Griffin, 'Studying Fascism in a Postfascist Age,' 1.

96 A. James Gregor, Interpretations of Fascism (sixth edition) (Brunswick, New Jersey: Transaction Publishers, 2009), xxvi-xxvii.

97 Roger Eatwell, 'Introduction: New Styles of Dictatorship and Leadership in Interwar Europe,' Totalitarian Movements and Political Religions 7, no. 2 (June 2006): 132.

98 Zeev Sternhell, Maurice Barrès et le nationalisme français (Bruxelles: Editions Complexe, 1985); Zeev Sternhell, Ni droite ni gauche: L'idéologie fasciste en France (Paris: Editions du Seuil, 1983).

99 Bar-On, Where Have All The Fascists Gone?, 15, 26-27. 
(thirteen characteristics), and Robert O. Paxton (eight characteristics). Here is J.J. Linz's early, maximalist definition of fascism:

hyper-nationalist, often pan-nationalist, anti-parliamentary, anti-liberal, anti-communist, populist and therefore anti-proletarian, partly anticapitalist and anti-bourgeois, anti-clerical, or at least, non-clerical movement, with the aim of national social integration through a single party and corporative representation not always equally emphasized: with a distinctive style and rhetoric, it relied on activist cadres ready for violent action combined with electoral participation to gain power with totalitarian goals by a combination of legal and violent tactics. ${ }^{100}$

The Italian historian Emilio Gentile defined fascism in the following manner and argued that it emerged with all its traits between 1921 and 1925 in Italy:

A nationalist and revolutionary, anti-liberal and anti-Marxist political movement with a social base mostly within the middle class; organized as a 'party militia'; having a totalitarian vision of politics and the state, and an ideology based on myth, virilistic and anti-hedonist, sacralized as a political religion affirming the primacy of the nation seen as an ethnically homogeneous organic community, that is organized hierarchically into a corporative State; belligerently advocating a policy of grandeur, power and conquest aimed at creating a new order and a new supranational civilization. ${ }^{101}$

Stanley Payne's proposed thirteen characteristics of fascism. ${ }^{102}$ Payne provides examples of fascist ideologues, movements, political parties, and regimes that fit his definition of fascism. Yet, Payne also differentiates between fascists, the radical right, and conservative right. ${ }^{103}$ Fascist ideologues include Giovanni Gentile, Benito Mussolini, and Adolf Hitler, among many others. Fascist movements existed throughout Europe in the interwar years from the British Union

\footnotetext{
100 Juan José Linz, 'Some Notes toward a Comparative Study of Fascism in Sociological Historical Perspective,' in Fascism: A Reader's Guide, ed. Walter Laqueur (Berkeley: University of California Press, 1976), 12-13.

101 Emilio Gentile, The Origins of Fascist Ideology 1918-1925 (New York: Enigma Books, 2005), xiii.

102 Stanley G. Payne, Fascism: Comparison and Definition (Madison: The University of Wisconsin Press, 1980), 7.

103 Payne, A History of Fascism, 15.
} 
of Fascists to the Romanian Iron Guard. These movements tended to emphasize style, glorify violence, and to have shirt colors borrowed from the shirt movement of the Bolsheviks. ${ }^{104}$ Full-fledged fascist regimes in power included Italy (1922-1943) and Nazi Germany (1932-1945), although in Romania, Hungary, and Spain fascists governed briefly or in coalition. Nazi collaborationist regimes such as the Ustasha in Croatia (1941-1942), Vichy in France (1940-1944), and the priest-politician Josef Tiso in Slovakia (1939-1945) sympathized with Nazi ideals and helped implement the 'final solution' against the Jews and other 'enemies of the nation'. Yet, Vichy France and Franco's Spain were, for Payne, too conservative to be considered fascist.

For Paxton, fascism includes the following characteristics: (1) obsessive preoccupation with community decline, victimhood, and decline; (2) compensatory cultures of unity, energy, and purity; (3) mass-based party of committed nationalist militants; (4) work with established elites in uneasy collaboration; (5) goal of abandoning democracy; (6) redemptive violence without legal or moral restraints; (7) internal cleansing; and (8) external expansion. ${ }^{105}$ Yet, Paxton also argued that we must pay attention to the five 'stages of fascism' (i.e., creation of fascist movements, rooting as parties in the political system, the acquisition of power, the exercise of power, and radicalization or entropy), as much as to what fascists say. ${ }^{106}$ It is important to note that most fascists never attained the regime phase, although interwar Europe saw fascist ideologues, movements, and political parties of varying success levels.

The fascist and Nazi projects were defeated in 1945, but fascism in its ideology, movement, and party permutations persisted in the postwar period. The French neo-fascist Maurice Bardèche (1907-1998), Russian neo-fascist intellectual Aleksandr Dugin, the French nouvelle droite led by Alain de Benoist (b. 1943), and the neo-fascist Italian Movimento Sociale Italiano [MSI; Italian Social Movement] are examples of fascism as ideology, movement - Dugin and de Benoist are part of the European New Right - and political party after World War Two. ${ }^{107}$ While some scholars argue that fascism was epochal (for Payne,

\footnotetext{
104 Payne, Fascism: Comparison and Definition, 12.

105 Robert O. Paxton, The Anatomy of Fascism (New York: Alfred A. Knopf, 2004), 18.

106 Robert O. Paxton, 'The Five Stages of Fascism,' The Journal of Modern History 70, no. 1 (March 1998): 1-23.

107 Roger Griffin, 'Foreword: Another Face? Another Mazeway? Reflections on the Newness and Rightness of the European New Right,' in Bar-On, Where Have All The Fascists Gone?, vii-xvi; Tamir Bar-On, Rethinking the French New Right: Alternatives to modernity (London: Routledge, 2013), 13; 81-109; 129-131; Anton Shekhovtsov, 'The Palingenetic Thurst of Russian Neo-Eurasianism: Ideas of Rebirth in Aleksandr Dugin's Worldview,' Totalitarian Movements and Political Religions 9, no. 4 (December 2008): 491-506.
} 
the epoch of fascism was from 1914-1945), or a moment in the Italian past, ${ }^{108}$ others thinkers such as Nigel Copsey insist that fascism was amorphous, adaptable, and continued after the end of the Second World War (including through the metapolitics of the French nouvelle droite). ${ }^{109}$ In the context of an antifascist consensus after the Second World War, fascists after the war tended not to openly declare their support for fascism. Other questions remain about fascism. Was Franco a fascist? How about Tiso in Slovakia? Or Peron in Argentina? Did fascism spread beyond Europe? Griffin argues that fascist movements could be found in South Africa, Japan, Brazil, Chile, and Argentina. ${ }^{110}$ The rise of the project of European integration in Western Europe, as well as socialism in the Soviet Union and Central and Eastern Europe, cemented a pan-European anti-fascist consensus from the end of the Second World War until 1989. Growing ultra-nationalism in the Balkans after the disintegration of Yugoslavia and the Bosnian War (1992-95), as well as genocides in Rwanda (1994) and Sudan (beginning in 2003), provided further impetus for the creation of the International Criminal Court in 1998 and new accusations of fascism.

\section{What is Islamism?}

One must differentiate between Islam as a religion and civilization, and Islamism as a modern political movement. Bassam Tibi points out that Islam is a moral system, a faith, or 'a religion of divine precepts,' while Islamism is 'a political concept of order.'111 For Tibi, whereas Islam is a religion, Islamism is 'religionised politics.' ${ }^{12} \mathrm{He}$ adds that it is 'the politicization of Islam that produces the ideology of Islamism,' while such politicization of Islam, in the form of contemporary Islamist movements (particularly terrorist groups of the takfiri variety such as ISIS), is 'unprecedented in the history of Islam.' ${ }^{113}$ Jeffrey Bale, however, could see the inspiration for Islamism in the original Muslim

108 Payne, A History of Fascism; De Felice, Fascism, 8.

109 Roger Griffin, The Nature of Fascism (London: Pinter, 1991), 146-147; Nigel Copsey, "Fascism... but with an open mind": Reflections on the Contemporary Far Right in (Western) Europe,' Fascism: Journal of Comparative Fascist Studies 2 (2013): 1-17, accessed July 19, 2018, doi: 10.1163/22116257-00201008.

110 Griffin, Fascism, 228-244.

111 Bassam Tibi, 'Islamism, Peace and the Maghrib,' Sixteenth Annual George A. Kaller Lecture, January 12, 2000, accessed September 1, 2017, http://www.adelinotorres.com/islam/ BASSAM\%2oTIBI-Islamism-peace-Maghreb.pdf

112 Bassam Tibi, Islamism and Islam (New Haven: Yale University Press, 2012), 1.

113 Tibi, Islamism and Islam, 3. 
conquests and the 'missionary spirit' of Islam. ${ }^{114}$ The French political scientist Gilles Kepel points out that Islamism is primordially a political rather than religious movement. ${ }^{115}$ The core of Islamism is a concept of political order (nizam siyasi) dubbed by the Islamists themselves as 'God's rule' (hakimiyyat Allah), which is incompatible with a secular, democratic order ruled by humans. ${ }^{116}$ All Islam after the first four caliphs is viewed by Islamists as degenerate and thus the aim is to re-institute the model Muslim community of the Prophet Muhammad in the Medina of the seventh century. ${ }^{117}$

In addition, Veković uses Tibi to summarize the Islamist posture, which he argues is modern and revolutionary:

The major creed of Islamism is expressed in the Arabic term din-wadawla (unity of state and religion) under a system of constitutionally mandated sharia law. Thus, according to Tibi, Islamism is not faith, but rather the imposition of a political system in the name of faith. In other words, Islamism is a specific interpretation of Islam, but it is not Islam. Islamism calls for a return of Islamic history and glory, but the state to which it seeks to return is an 'invented tradition' (Tibi borrows this term from Eric Hobsbawn). According to him, this imagined system of God's rule has never in fact existed in Islamic history. Thus, in his point of view, Islamism does not herald a revival of Islam, but is rather a re-invention of tradition. ${ }^{118}$

Daniel Pipes also distinguishes between Islam the religion and Islamism the political ideology. Pipes writes that Islamism is 'an ideology that demands complete adherence to the sacred law of Islam and rejects as much as possible outside influence, with some exceptions (such as access to military and medical technology). ${ }^{119} \mathrm{He}$ adds that Islamism is 'imbued with a deep antagonism towards non-Muslims and has a particular hostility towards the West.'120

\footnotetext{
114 Jeffrey Bale, 'Islamism and Totalitarianism,' Totalitarian Movements and Political Religions 10, no. 2 (2009): 75 .

115 Gilles Kepel, Jihad: The trail of political Islam (London: I. B. Tauris, 2006), viii.

116 Tibi, Islamism and Islam, 3.

117 Brachman, Global Jihadism: Theory and practice, 5.

118 Marko Veković, 'Bassam Tibi, "Islamism and Islam", Politics and Religion 2, no. 3 (2013): 440.

119 Daniel Pipes, 'Distinguishing between Islam and Islamism,' Center for Strategic and International Studies, June 30, 1998, published at danielpipes.org, accessed February 6, 2017, http://www.danielpipes.org/954/distinguishing-between-islam-and-islamism.

120 Pipes, 'Distinguishing between Islam and Islamism.'
} 
For Pipes, Islamism 'amounts to an effort to turn Islam, a religion and civilization, into an ideology.'121 Islamism is an '-ism' and hence akin to fascism and nationalism. ${ }^{122}$ Islamism, insists Pipes, 'offers a way to control the state, run society, and remake the human being.' ${ }^{\prime 23}$ It is a 'modern ideology' and hence a repudiation to those that do not qualify it as a political ideology. In addition, Islamism is a 'radical utopian scheme' like fascism and communism, as well as 'an Islamic-flavored version of totalitarianism.'124 Pipes is thus a proponent of the 'Thou Shall Compare' camp and has even supported the 'Islamofascism' camp. In 2001, Pipes stated the following: 'I equate Islamism with fascism ... . Islamism is a totalitarian ideology. An Islamist is a danger in the same way a fascist is a danger.'125

For Martin Kramer, the term Islamism first appeared in French in the mideighteenth century and it was often a synonym for Islam. ${ }^{126}$ He notes that 'Islamic fundamentalism' was the preferred term in academia in the 1970s, and was borrowed from the West to initially describe Protestant churches and organizations that insisted on the literal, divine origin of the Bible. ${ }^{127}$ John Esposito argued that the term fundamentalism smacked of judgment, fanaticism, and terrorism and employed terms such as 'Islamic revivalism' and 'Islamic activism.' ${ }^{128}$ Edward Said insisted that the term fundamentalism 'had come to be employed against Islam.'129

Other scholars have used the terms 'political Islam', 'activist Islam', and 'Islamic militancy'.130 Martin Kramer points out that the term Islamism migrated to the Anglophone world from France (i.e., the French term Islamisme) in the late 1970s and early 1980s, particularly as French scholars attempted to grapple with the global implications of the Islamic Revolution in Iran in 1979. ${ }^{131}$ Gilles Kepel was one of the first to use the term Islamism in English, in

\footnotetext{
121 Ibid.

122 Ibid.

123 Ibid.

124 Ibid.

125 Boehlert, 'Islamism is fascism.'

126 Martin Kramer, 'Coming to Terms: Fundamentalists or Islamists?' Middle East Studies Quarterly (Spring 2003): 65-77.

127 Kramer, 'Coming to Terms,' 65-77.

128 John L. Esposito, The Islamic Threat: Myth or Reality? (New York: Oxford University Press, 1992), 7-8.

129 Edward Said, Covering Islam (New York: Vintage, 1997), xvi.

130 Kramer, 'Coming to Terms.'

131 Ibid.
} 
an English translation of his classic Le Prophète et le Pharaon. ${ }^{132}$ This distinction is questioned by Bale who sees Islamism as the 'right-wing pole' of the political Islam spectrum. ${ }^{133}$ As a term, Islamism did gain in ascendancy over fundamentalism in policy circles, including in the USA, as policymakers became concerned about the negative impact of terms such as fundamentalism on Muslims. ${ }^{134}$

A critical reader on political Islam argues that political Islam and Islamism will be used interchangeably, while some scholars make a distinction between Islamists and fundamentalists. ${ }^{135}$ Kramer correctly points out that Islamists generally oppose the use of the term Islamism, claiming that their political beliefs and goals are simply an expression of Islamic religious belief. ${ }^{136}$ Yet, Islamists embrace terms in Arabic that are roughly equivalent to Islamism, including islamiyyun ['Islamic ones']. In contrast, fascists in the interwar years such as Benito Mussolini accepted the term fascism to describe themselves (although this was not the rule among all fascists), but postwar fascists are likely to deny the fascist label. ${ }^{137}$ Abbassi Madani (b. 1931), a founder of the Front Islamique du Salut [FIS; Islamic Salvation Front], reprimanded François Burgat for using the term Islamism in his 1988 book:138 'In your book, you must first of all change the title! Why Islamism? It is Islam that is at work in Algeria, nothing but Islam. We are Muslims!'139

Sheri Berman argues that Islamism is 'the belief that Islam should guide social and political as well as personal life. ${ }^{140}$ Or, W.E. Shepard posits that Islamists insist that their ideology 'guides society as a whole and that law must

132 Gilles Kepel, Le Prophète et le Pharaon: Aux sources des mouvements islamistes (Paris: Le Seuil, 1984). The book was translated as Muslim Extremism in Egypt: The Prophet and Pharaoh (Berkeley: University of California Press, 1985).

133 Bale, 'Islamism and Totalitarianism.'

134 Kramer, 'Coming to Terms.'

135 Frederic Volpi, ed., Political Islam: A critical reader (London: Routledge, 2011).

${ }_{13} 6$ So, for example, Ayatollah Mohammad Hussein Fadlallah, the spiritual mentor of Hezbollah (the Party of God) in Lebanon. See Kramer, 'Coming to Terms.'

137 'The Doctrine of Fascism' (La dottrina del fascism), first published in Enciclopedia Italiana in 1932, was written largely by Fascist philosopher Giovanni Gentile, while only the second part (Dottrina politica e sociale) ('The Political and Social Doctrine of Fascism') is the work of Mussolini himself. See Benito Mussolini, The Political and Social Doctrine of Fascism (London: Hogarth Press, 1933). For postwar neo-fascism, see Bar-On, Where Have All The Fascists Gone?, 3-4.

138 François Burgat, L'Islamisme au Maghreb: La voix du Sud (Paris, Karthala, 1988).

139 Abbassi Madani, quoted in Kramer, 'Coming to Terms.'

140 Sheri Berman, 'Islamism, Revolution, and Civil Society,' Perspectives on Politics 1, no. 2 (June 2003): 258 . 
be in conformity with the Islamic sharia.'141 Volpi defines Islamism as 'the political dynamics generated by the activities of those people who believe that Islam as a body of faith has something crucial to say about how society should be organized, and who seek to implement this idea as a matter of priority.'142

Jeffrey Bale argues that 'Islamism,' 'political Islam', and 'Islamic fundamentalism' are not synonymous. ${ }^{143}$ Bale insists that Islamism can be viewed as a subset of 'activist Islamic fundamentalism.' ${ }^{144} \mathrm{He}$ writes that under the rubric of 'political Islam', he would include 'all of the ideologies and movements that actively aim to politicise Islam or Islamise politics,' which includes 'a very broad umbrella that ranges - left to right' - from 'Islamic socialism' (not to be confused with Western variants of socialism) (e.g., Ali Shariati, a key ideologue of the Iranian Revolution) to 'Islamic liberalism' (not to be confused with Western liberalism) (e.g., the majlis al-shura or consultative council) to 'moderate Islamic reformism' (e.g, advocated by Muhammad 'Abduh, before the Salafiyya movement was transformed into a puritanical current of Islamism by Muhammad Rashid Rida), to the 'Islamic right'.145

Charles Hirschkind notes that political Islam 'involves an illegitimate extension of the Islamic tradition outside of the properly religious domain it has historically occupied.'146 For Hirschkind, not all forms of political Islam connote 'capture of the state' and the modern secular state undertakes many functions that are religious. ${ }^{147}$ Moreover, he points out that the notion of separation of church and state has different meanings in the European and Middle Eastern contexts. ${ }^{148}$ Cynthia Farahat confirms this point when she notes that the current, allegedly 'secular' military regime led by President Abdel Fattah el-Sisi in Egypt and the previous government under the Muslim Brotherhood both implemented the sharĩah as 'the principal of legislation' in the country. ${ }^{149}$

\footnotetext{
141 William E. Shepard, Sayyid Qutb and Islamic Activism: A Translation and Critical Analysis of Social Justice in Islam (Leiden: E.J. Brill., 1996), 40.

142 Frederic Volpi, 'Introduction: Critically Studying Political Islam,' in Political Islam: A Critical Reader, ed. Frederic Volpi (London: Routledge, 2011), 1.

143 Bale, 'Islamism and Totalitarianism,' 92.

144 Ibid.

145 Ibid.

146 Charles Hirschkind, 'What is Political Islam?' in Political Islam: A Critical Reader, ed. Frederic Volpi (London: Routledge, 2011), 14.

147 Hirschkind, 'What is Political Islam?' 13-14.

148 Ibid., 14.

149 Cynthia Farahat, 'The Arab Upheaval: Egypt's Islamist Shadow,' Middle East Quarterly (Summer 2011): 24 .
} 
Euben and Qasim Zaman define Islamism in a manner that would omit Sufi, Salafist, and Muslim modernist tendencies in Islam: Contemporary movements that 'attempt to return to the scriptural foundations of the Muslim community' with the goal of 'restoring the primacy of the norms derived from these foundational texts to collective life' in an 'explicitly and intentionally political' manner. ${ }^{150}$ They also point out that what distinguishes Islamists from other political forces is their total and unambiguous commitment to 'the public implementation of the sharia ("Islamic law") through the agency of the state."151

Following the Arab Spring, for some commentators Islamism became compatible with democracy. Is Mohamed Morsi, the former Islamist President of Egypt, really a democrat? How about Recep Tayyip Erdoğan, the current Islamist President of Turkey? Is the party he belongs to, the Justice and Development Party, Islamist, conservative, or neo-Ottomanist?

Mehdi Mozaffari points out that Islamism is simultaneously an 'ideology', a 'movement-organisation', and a 'form of government'. ${ }^{152} \mathrm{He}$ defines Islamism as 'a religious ideology with a holistic interpretation of Islam whose final aim is the conquest of the world by all means. ${ }^{\prime 153}$ For Mozaffari, Islamism is a combination of 'Islam' as a religion and an 'ism', or a modern political ideology akin to fascism or socialism. ${ }^{154}$ He points out that radical Islamists tend to stress the more militaristic and Medina aspects of the first Islamic community created by Muhammad rather than the more tolerant Mecca phase of Islam. ${ }^{155}$ According to Mozaffari, Islamism is a complex phenomenon with multiple dimensions and various ramifications, but it is a totalitarian ideology. He argues that despite sectarian and other differences between various Islamist groups, their final objective remains the same: 'They all aim at the re-instauration of Islamic might in the world, ${ }^{156}$ whether through violent or non-violent means. Islamism, Mozaffari notes, is based on the totalitarian trinity of Dîn [Religion], Dunya [Way of life] and Dawla [Government]. ${ }^{157}$ An Islamist, insists Mozaffari, is 'responsible to his Leader and before Allah,'158 thus lending credence to the notion of Islamism as a modern, totalitarian political ideology.

\footnotetext{
150 R.L. Euben and M.Q. Zaman, ed., Princeton Readings in Islamist Thought: Texts and Contexts from al-Banna to Bin Laden (Princeton: Princeton University Press, 2009), 4.

$15^{1}$ Euben and Zaman, Princeton Readings in Islamist Thought, 11.

152 Mozaffari, 'What is Islamism?' 21.

153 Ibid.

154 Ibid., 21-22.

155 Ibid., 22-23.

156 Ibid., 17.

157 Ibid., 23 .

$15^{8}$ Ibid., 22.
} 
Islamist thinkers confirm Mozaffari's claims about Islamism as a form of totalitarianism. Sayyid Qutb argued that the aim of jihad was not merely spiritual excellence, but the Islamic conquest of the world in order to establish 'Divine authority': 'throughout the earth to the whole of mankind, as the object of this religion [Islam] is all humanity and its sphere of action is the whole earth.'159 Or, Sayyid Abu al-A'la Mawdudi (1903-1979), an Indian-born Pakistani Islamist, also highlighted the totalitarian conception of politics of the Islamists:

A state of [the Islamist] sort cannot evidently restrict the scope of its activities. Its approach is universal and all-embracing. Its sphere of activity is coextensive with the whole of human life. It seeks to mould every aspect of life in consonance with its moral norm and programmes of reform. In such a state, no one can regard any field of his affairs as personal and private. Considered from this perspective the Islamic state [i.e., the Islamist state] bears a kind of resemblance to the fascist or communist state. ${ }^{160}$

Diverse Islamist ideologues from Ala Mawdudi to Hassan al-Banna and Sayyid Qutb and Ayatollah Khomeini have influenced contemporary Islamist movements. Other important figures who inspired various Islamist movements are Rashid Rida, Muhammad Asad, Said Nursî, Taqiuddin al-Nabhani, Ali Shariati, Navvab Safavi, Yusuf al-Qaradawi, and Rashid al-Ghannushi. Islamist movements have included the Egyptian Muslim Brotherhood from the 1920 s to the Taliban in the 1990s. Islamist political parties range from the Justice and Development Party in Turkey to Ennahda in Tunisia, which has been part of the ruling government coalition. Islamist regimes in power today include the Islamic Republic of Iran and the Kingdom of Saudi Arabia.

Various scholars claim that Islamism was created in the aftermath of the shock of the loss of the Caliphate in 1924; the rise of nationalist movements in the Arab world that challenged the colonialist 'conspiracy' of the Sykes-Picot agreement between Britain and France in 1916; ${ }^{161}$ accelerated processes of modernization; the rise of mass politics in the Arab world; and the creation of

159 Sayyid Qutb, Ma'âlim fi al-Tariq (Milestones: 1964), Chapter 4, available at http://www .youngmuslims.ca/online_library/books/milestones/Introduction.asp, quoted in Mozaffari, 'What is Islamism,' 29.

16o S. A. al-A'la Mawdudi, Islamic Law and Constitution (Delhi: Taj Company, 1986 [196o]), 144-145, quoted in Bale, 'Islamism and Totalitarianism,' 73.

161 Bassam Tibi, La conspiración: El trauma de la política árabe (Barcelona: Herder, 2001). 
the first major contemporary Islamist movement in the Arab world in Egypt in 1928, the Muslim Brotherhood. ${ }^{162}$

Islamism arises around the same period as fascism in Europe. Some scholars have noted that Islamists such as Hajj Mohammed Effendi Amin al-Husseini, the Grand Mufti of Jerusalem in Palestine, collaborated with the Nazis. ${ }^{163}$ Tibi points out that for Islamists there is a perception of the Jews as the chief enemy conspiring against Islam because Jews are thought to be pursuing a 'Jewish world order' in conflict with the geopolitical, political, and theological goals of Islamists. ${ }^{164}$ For Hitler, the Jew was the primary enemy (simultaneously a capitalist, communist, and 'rootless cosmopolitan' seeking world domination), which needed to be exterminated for the good of the German Volk. ${ }^{165}$ Yet, as mentioned earlier, not all fascists were anti-Semites. Sharing anti-Semitism does not necessarily mean that Islamists and fascists are ideologically equivalent. Moreover, whereas some fascist movements invited Jews into their ranks, Islamists would never allow Jews into their movements, unless they convert.

According to Fred Halliday, Islamism is a modern phenomenon dating to the late 1920 and can be defined in the following manner: 'the organised political trend, owing its modern origin to the founding of the Muslim Brotherhood in Egypt in 1928, that seeks to solve modern political problems by reference to Muslim texts. ${ }^{166}$ François Burgat argues that the history of Islamism can be separated into three time frames: The first time period can be dated from Sayyid Jamāl ad-Dīn al-Afghānī (1838/1839-1897) to Muhammad ibn 'Abd al-Wahhab (1703-1792) and was devoted to political resistance against Western colonization; the second time period stretches from the independence of Arab and Muslim states until the early 199os; and the third period emerges with the growing pull of al-Qaeda in the 1990 and new millennium. ${ }^{167}$ Yet, perhaps Burgat conflates those earlier movements (i.e., a long series of Islamic revivalism) with Islamism per se.

\footnotetext{
162 Volpi, 'Introduction,' 2.

163 Meir-Levi, Upside Down; Küntzel, Jihad and Jew-Hatred.

164 Tibi, Islamism and Islam, 6.

165 Adolf Hitler, Mein Kampf (trans. James Murphy) (London: Hurst and Blackett, 1939).

166 Fred Halliday, 'The Left and the Jihad,' Open Democracy, April 6, 2011, accessed February 9, 2017, https://www.opendemocracy.net/globalization/left_jihad_3886.jsp.

${ }_{167}$ François Burgat, 'From National Struggle to the Disillusionments of Recolonization: The triple Temporality of Islamism,' in Political Islam: A Critical Reader, ed. Frederic Volpi (London: Routledge, 2011), 29-41.
} 


\section{Dare to Compare: Islamism and Fascism}

Recall that I support the 'Dare to compare' camp. As noted earlier, some scholars such as Walter Laqueur 'dared to compare' Islamist and fascist movements and regimes by highlighting their similarities and differences.

Laqueur uses the term 'Islamic fascism' in relation to the Islamic Revolution in Iran and asks 'whether this was a new reality or mere defamation by the enemies of Islam,' but ultimately argues that its origins date to the clerical fascism of the $1930{ }^{168}$ Are fascism and religion incompatible because 'both were holistic weltanschauungen \{worldviews\} laying claim to the whole human being in all respects'?169 Thus, can a religious regime, whether Tiso's Slovakia or the Islamic Republic of Iran be fascist when fascism is a secular ideology? In a propagandistic vein, Christopher Hedges argues that the Christian fundamentalist right in the USA longs for an 'American fascism'; a fascism wrapped in the Bible and the flag. ${ }^{170}$ In practice, Laqueur points to alliances between religious authorities and secular fascist regimes such as the Lateran Pacts (1929), which saw Fascist Italy create the Vatican state. Laqueur points out that Islam, like fascism, is for the Islamists not merely a religion, but also 'a comprehensive political and social order from which no deviation is permitted.'171

Mozaffari is adamant that Islamism is totalitarian. Contemporary and revolutionary political ideologies such as communism, fascism, and Nazism are examples of 'political religion.' ${ }^{172}$ For Emilio Gentile, 'political religions' are constructed around a monopoly of power, ideological monism, and the total subordination of the individual and collectivity to its sacred commandments. ${ }^{173}$ Yet, Mozaffari points out that Islamism is a unique ideology: 'it is already a religious phenomenon, and labels like "civil", "secular" or "political" religions do not apply to it. That is, Islamism constitutes the politicization of a genuine religion, namely, Islam. "Clerical fascism" is a concept, which comes closest to Islamism.' ${ }^{174}$ For John Pollard, 'clerical fascism' includes individuals,

168 Laqueur, 'Fascism in the Twenty-First Century?' 51.

169 Ibid.

170 Christopher Hedges, American Fascists: The Christian Right and the War on America (New York: Free Press, 2006).

171 Laqueur, 'Fascism in the Twenty-First Century?' 52.

172 Emilio Gentile, 'The secularisation of Politics: Definitions, Interpretations and Reflections on the Question of Secular Religion and Totalitarianism,' Totalitarian Movements and Political Religions 1, no. 1 (Summer 200o): 40. See also Emilio Gentile Politics as Religion (Princeton, NJ: Princeton University Press, 2006).

173 Gentile, 'The secularisation of Politics,' $x v$.

174 Mozaffari, 'What is Islamism?' 21. 
members of the clergy or laity, who were supporters or Fascist 'fellow travelers' in Italy, or became paid members of fascist movements or regimes. ${ }^{175}$ Clerical fascism initially, then, refers to sections of the Italian Catholic Church that supported Fascism and later included fascist supporters amongst Catholics in Germany and Catholics in occupied Europe such as in Austria, Belgium, Slovakia, or Hungary. It perhaps also came to mean general Christian clerical support for fascism in Europe (including amongst Protestants and Orthodox Christians) as an antidote to modernizing forces and a defense of ecclesiastical interests. Did some clerics and fascist movements, as Feldman and Turda ask, see fascists or Nazis as sufficiently Christian and even "holy" redeemers of the nation or race'? ${ }^{176}$ Perhaps the most famous example of a clerical fascist movement was the rabidly anti-Semitic and pro-Orthodox Iron Guard/Legion of the Archangel Michael in Romania, which fused Orthodox Christianity and fascism. Yet, one scholar suggested that the Iron Guard superseded the canonical boundaries of the Orthodox Church and were hence not 'clerical fascists.' ${ }^{177}$ In Croatia, 'clerical fascists' could be found amongst the pro-Nazi, collaborationist Ustasha, where some clerics even participated in fascist violence and genocide. For a more thorough understanding of clerical fascism, national context matters. So, for example, the Church hierarchy in Ireland never supported the fascist Blueshirts; some clerics within the British Union of Fascists hoped to reconcile Christian faith and fascism; and the Catholic agenda was largely embraced by Belgian fascists. ${ }^{178}$

At this stage, I use Griffin's minimalist definition of fascism to flesh out whether Islamists are fascists. If we recall, Griffin argued that fascism is revolutionary, as well as 'a genus of political ideology whose mythic core in its various permutations is a palingenetic form of populist ultra-nationalism.179 Islamism

175 Jonathan Pollard, 'CClerical Fascism”: Context, Overview and Conclusion,' Totalitarian Movements and Political Religions 8, no. 2 (June 2007): 434. For a more elaborate treatment of 'clerical fascism', see Matthew Feldman and Marius Turda (with Tudor Georgescu), Clerical Fascism in Interwar Europe (New York: Routledge, 2008). Also, see Matthew Feldman and Marius Turda, “'Clerical Fascism” in Interwar Europe: An Introduction,' Totalitarian Movements and Political Religions 8, no. 2 (June 2007): 205-212. This aforementioned journal issue published a special issue on 'clerical fascism'.

176 Feldman and Turda, 'Clerical Fascism” in Interwar Europe,' 206.

177 See Valentin Săndulescu, 'Sacralised Politics in Action: The February 1937 Burial of the Romanian Legionary Leaders Ion Moţa and Vasile Marin,' Totalitarian Movements and Political Religions 8, no. 2 (June 2007), 259-269. For the Iron Guard as 'clerical fascist', see Roger Eatwell, 'Reflections on Fascism and Political Religion,' 148.

178 Feldman and Turda, '“Clerical Fascism” in Interwar Europe,' 207-210.

179 Griffin, 'Studying Fascism in a Postfascist Age,' 5 . 
is definitely not fascism because it desires the abolition of nation-states; attacks nationalism as a false form of loyalty because it privileges the secular nation and man-made laws above the ummah and sharīah; and views nations as artificial creations, which divide Muslims and inhibit pan-Islamic unity. Whereas Islamists recognize the mobilizing power of nationalism in the struggle against colonialism and 'enemy occupiers', they 'define patriotism according to the creed of Islam' and nationalists base their primordial identity 'according to territorial borders and geographical boundaries.' ${ }^{\prime} 10$ Islamism is palingenetic as the hope is for a pan-Islamic community rising from the ashes of foreign domination and neo-colonialism, as well as local 'decadence' due to authoritarian, secular regimes (especially those regimes politically close to the West). The reborn ummah will lead to the emergence of more just society regulated by the sharīah. In practice, 'nationalist Islamists' such as Hamas have clashed with 'global Islamists' such as al-Qaeda or ISIS over the notion of 'near enemy' and 'far enemy', but both want the sharîah imposed in the Muslim world. Both privilege the loyalty of the Muslim community above attachment to the nation or state. Finally, Islamists are, like fascists, perhaps populists as they appeal to the people above the 'corrupt', secular government elites. Yet, populism comes in many ideological stripes and the fact that both are populists does not make Islamists fascists. Islamists are populists, but the type of system they want to impose is not by or for the people (democracy), but based on God's law. Moreover, most Islamists will never consider themselves fascists, instead seeing fascism as a godless, secular ideology. Islamists are perhaps more anti-Semitic than fascists, who in some movements accepted Jews into their ranks. As the Hamas Covenant makes clear, not only will Israel be 'obliterated' by Muslim forces, but 'our struggle against the Jews is very great and very serious.' ${ }^{181} \mathrm{Jihad}$ is seen as a duty in order to liberate Israel from the Jews. For Hamas, Jews allegedly caused the Second World War, the Holocaust, world revolutions, the creation of Israel, and they seek to rule the world and destroy Muslim unity. The Hamas worldview includes the conspiratorial anti-Semitism of The Protocols of the Elders of Zion and Mein Kampf rolled into one. ${ }^{182}$ For Hamas, peace is only possible through the elimination of Israel and the Jews. This confirms Sifaoui's aforementioned position about Islamism's 'will to exterminate the Jews.' Yet, it does not necessarily prove that Islamism is a form of fascism.

18o Hassan al-Banna, Da'watuna'(Our message), in Jaridat al-Ikhwan al-Muslimin (1353/1935), quoted in Mura, 'A Genealogical Inquiry into Early Islamism: The Discourse of Hassan alBanna,' Journal of Political Ideologies 17, no. 1 (2012): 74.

181 Avalon Project, 'The Covenant of the Islamic Resistance Movement.'

182 Herf, 'Why they Fight.' 


\section{Conclusion}

Undermining his own 'end of history' thesis after 9/11, in 2002 Francis Fukuyama posited that history had re-started and that Islamists were at the forefront in challenging liberalism as the hegemonic ideology. ${ }^{183}$ Fukuyama could even support the 'Islamofascism' thesis: 'A strong finger of blame for the rise of Islamo-fascism must point at Saudi Arabia.'184 Both Islamists and fascists challenge Fukuyama's end of history thesis. Islamists have been on the march in Iraq, Syria, Yemen, and other countries. Neo-fascists have changed their tactics and are constrained by the anti-fascist consensus and the European Union.

I began by showing how the popular press have revived comparisons between Is Is and fascism. I noted that such comparisons between Islamism and fascism proliferated in the post-9/11 climate. I also pointed out that the Obama administration, unlike the previous Bush administration, does not compare Islamism to fascism in order to win hearts and minds in the Muslim world. I also highlighted examples of the Islamism-fascism comparison, which predated 9/11. I then proposed a four-fold typology of four discourses in respect of the comparison between Islamism and fascism. In order to assess the validity of the Islamism-fascism comparison, I surveyed various definitions of fascism and Islamism. Against the 'Though shall not compare', 'Islamosfascism', and 'Islamofascism as epithet' camps, I 'dared to compare' Islamism and fascism as modern political ideologies. I posited that while Islamism and fascism are different political ideologies with differing visions of human nature, the ideal state, and historical processes, both ideologies share the quest for totalitarianism. Both Islamism and fascism mobilize the masses, ignoring class distinctions, in order to combat internal or external threats. As Michael Whine explains, both replace the practice of religion with their own monopolistic ideology, relying on mass communication and suppression of dissent in order to construct a single party regime, a new state with the vision of a 'new man', and the aim of conquering existing society, which it believes has deviated from its ideal. ${ }^{185}$

While Islamism and fascism are different political ideologies, we should pay attention to what fascists and Islamists say and do. Griffin's or Sternhell's minimalist definitions of fascism do not fit the Islamists because fascists

\footnotetext{
183 Fukuyama, 'Has History Started Again?' 3-7.

184 Ibid., 6.

185 Michael Whine, 'Islamism and Totalitarianism: Similarities and Differences,' Totalitarian Movements and Political Religions 2, no. 2 (2001): 54-72.
} 
reject secular nationalism and socialism as Western constructs in favor of a pan-Islamic community of believers wedded to the sharíah. Perhaps the closest ideology to Islamism is clerical fascism. This is the perspective of Stephen Schwartz. He points out that the fascist Iron Guard in Romania during the interwar period and in World War Two was 'explicitly Christian - its official title was the "Legion of the Archangel Michael".'186 While clerical fascists could gain support in Croatia, Romania, Slovakia, and Portugal, fascism tended to make Christian supporters believe that it represented the best defense of Christian values against the onslaught of modernity, materialism, individualism, decadence, secularization, the atomization of society, capitalism, and communism. ${ }^{187}$ Fascism made it clear that in a dispute between the Christian faith and the fascist ideology, fascism prevailed. Islamism, too, often privileges the ideology and leader in the name of the faith. Yet, Islamism is not fascism and fascism is not Islamism. Clerical fascists could not, by definition, implement the New Testament because they were primordial fascists, but Islamists in power have implemented the shari $a h$. Moreover, whereas fascism connoted the sacralization of the political (i.e., converting the Party, State, Fatherland, or Race into objects of religious-like adoration), Islamism is rather a classic example of the politicization of religion as it is deeply wedded to Islam, hadiths, and alqur'ān with minimal participation of imāms. Thus, even Islamism is not a type of 'clerical fascism'. We should thus compare fascism and Islamism as totalitarian political ideologies, highlighting their similarities but also their important differences. Future research might compare and contrast the competing perspectives of Islamists and fascists in terms of the relationship between church and state; economic policies; organizational structure; or political rhetoric.

186 Schwartz, 'The Terrorist War against Islam.'

187 Pollard, 'CClerical Fascism”,' 443-444. 